\title{
Aortic root surgery with the CARDIOROOT vascular graft: results of a prospective multicenter post-market surveillance study
}

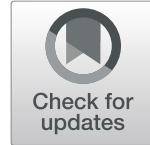

\author{
Giordano Tasca ${ }^{1 *}$ D, Jaroslav Lindner ${ }^{2}$, Laurent Barandon ${ }^{3}$, Petr Santavy ${ }^{4}$, Carlo Antona ${ }^{5}$, Jan Burkert ${ }^{6}$ and
} Amando Gamba ${ }^{1}$

\begin{abstract}
Background: Sparing Aortic Valve procedure requires to reproduction of the geometry of the physiologic anatomy of the aortic root. Thus, the materials adopted may make a difference. CARDIOROOT is a one-piece collagen-coated woven vascular graft with pseudo-sinuses, which was designed for use in the treatment of aortic root disease. We report the results of a prospective, multicenter, observational post-market surveillance study evaluating the safety and performance of the CARDIOROOT in patients requiring aortic root surgery.
\end{abstract}

Methods: Patients with aortic root disease suitable for treatment with a vascular graft with pseudo-sinuses CARDIOROOT graft were eligible for participation. The enrolled patients were assessed intraoperatively, postoperatively, at discharge and at 1-year. Sites assessed complications at each visit, and recorded any reported adverse events. The study endpoint was mortality and complications through 1-year post-procedure.

Results: Fifty-two patients were enrolled from 6 European centers. All procedures were technically successful. Operative mortality was 1.9\%: one patient suffered hemorrhagic shock unrelated to the graft 1 day following surgery. At 1-year follow-up the survival rate was $96.2 \%$, with a late death due to pneumonia 5 months postprocedure. Eleven serious adverse events occurred in 7 patients, which included cardiac complications (pericardial effusion, myocardial infarction and ventricular arrhythmia), infection (pericardial infection, deep sternal infection and superficial sternal infection), vascular disorders, including hemorrhagic shock and pleural effusion requiring drainage. Nine of the 11 events were deemed procedure-related by the local investigator, and all were deemed unrelated to the device. There were no reports of graft-related adverse events, infection, occlusion or graft failure.

Conclusions: The results of this 1-year follow-up study showed that the CARDIOROOT vascular graft is safe and effective for the treatment of aneurysmal aortic root in immediate and mid-term follow-up. However, longer term follow-up is needed before conclusions can be made on the long-term safety and effectiveness.

Trial registration: ClinicalTrials.gov Identifier: NCT01609270. Registered 31 May 2012.

Keywords: Aortic root surgery, Vascular graft, Sinus of Valsalva, CARDIOROOT

\footnotetext{
* Correspondence: giordano.tasca67@gmail.com

'Operative Unit of Cardiac Surgery, Cardiovascular Department, ASST-Lecco,

Ospedale "A. Manzoni", Via Dell'Eremo 9/11, 23900 Lecco, Italy

Full list of author information is available at the end of the article
}

(C) The Author(s). 2019 Open Access This article is distributed under the terms of the Creative Commons Attribution 4.0 International License (http://creativecommons.org/licenses/by/4.0/), which permits unrestricted use, distribution, and reproduction in any medium, provided you give appropriate credit to the original author(s) and the source, provide a link to the Creative Commons license, and indicate if changes were made. The Creative Commons Public Domain Dedication waiver (http://creativecommons.org/publicdomain/zero/1.0/) applies to the data made available in this article, unless otherwise stated. 


\section{Background}

Aortic root surgery is one of the most technically demanding procedures in cardiac surgery with higher risk of reoperation for bleeding and hospital mortality compared with a standard isolated aortic valve repair or replacement. When the aortic root disease is treated by a valve sparing technique, achieving a precise relationship among all the components of the aortic root and to restore near normal anatomy and function is imperative, and the materials used contribute greatly. The sparing aortic valve procedures have shown to be apt for the treatment of the aortic root diseases with excellent long-term results [1]. Although valve sparing procedures have been documented using completely straight tubular grafts, the use of a pre-formed graft with the shape of sinus of Valsalva has shown to allow for improved reproduction of normal aortic root physiology, and subsequently, physiologic results [2, 3]. Materials used to construct the prosthetic graft are important in order to optimize the graft's performance once implanted. For example, construction using the woven technique compared to a knitting technique results in fabric less porous and less prone to dilate over time [4-6]. The woven technique consists of interlacing two sets of yarn (warp and weft) oriented at 90 degrees to one another. This confers peculiar mechanical properties and features to the graft. Among these features, there are a surface smoothness, easy handling, a low water permeability and suture retention strength [7]. The orthogonal arrangement of the yarn components yields a low radial compliance property. This arrangement results in a graft less prone to dilate immediately after the operation, as well as over time, compared with those made by means of knitted technique $[4,6]$.

In addition, all prosthetic grafts require a sealant to stop and minimize bleeding. The presence of a sealant comprised of collagen has shown superior healing properties with respect to fibroblasts, and a thinner inner healing tissue (intimal layer formation) compared with other sealants [8].

CARDIOROOT (Intervascular SAS, La Ciotat, France) is one piece-design collagen-coated graft adopted in the repair or reconstruction of the aortic root. The unique design of the CARDIOROOT graft mimics the anatomy of the aortic root, and potentially allows physiologic flow and leaflets dynamics. This graft is made of woven polyester fabric coated with highly purified form of cross-linked Type I bovine collagen. The graft is constructed in three distinct regions including a Valsalva bulge, uncrimped with a drop shape, a woven tubular body above the Valsalva section and an uncrimped miniskirt collar underneath the Valsalva bulge. (See Fig. 1).

As a condition of commercial approval (Conformité Européene mark) for the CARDIOROOT vascular grafts,

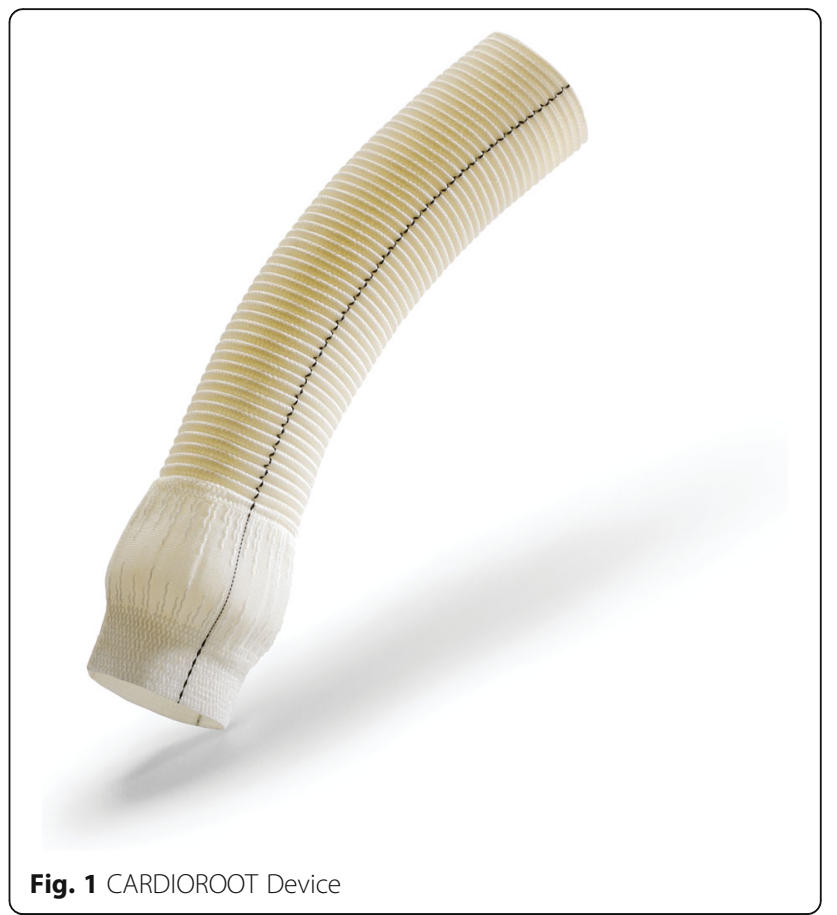

Intervascular SAS conducted a post-marketing surveillance registry of the CARDIOROOT vascular grafts in "real world" usage. This was a prospective, open-label, single-arm, multicenter, observational registry planned to enroll at least 50 subjects (Clinicaltrials.gov Reference Number: NCT01609270). The aim of the current study was to report the safety and performance of the CARDIOROOT vascular graft.

\section{Methods \\ Patients}

From November 2013 to June 2016, 52 patients (41 males, $79 \%$, mean age 58, range 21 to 79 years) were treated at 6 study centers in Europe (France, Italy and Czech Republic). Patients with aortic root disease who were suitable, according to the local Investigators, to be treated by a CARDIOROOT vascular graft implantation were invited to participate in the registry. Patients were excluded based upon the contraindications as specified in the CARDIOROOT Instructions for Use, as well as patients that required consecutive aortic surgery, patients with extensive coronary artery disease, and patients who required urgent/emergent surgery. The local Institutional Ethics Committee approved the study protocol and patients provided written informed consent before surgery and inclusion in the registry.

Table 1 shows the main clinical characteristics of the population. Pre-operative echocardiographic assessment showed an average left ventricular ejection fraction of $60 \% \pm 10 \%$, aortic valve stenosis presence in $19 \%$ of patients, an aortic valve regurgitation (at least moderate) 
Table 1 Demographics and pre-operative patient characteristics

\begin{tabular}{|c|c|}
\hline Variable & $\begin{array}{l}\text { Mean } \pm \text { standard deviation } \\
(\mathrm{SD}) \text { or } \mathrm{n} / \mathrm{m}(\%)\end{array}$ \\
\hline \multicolumn{2}{|l|}{ Demographic variables } \\
\hline Age (years), mean $\pm S D$ & $58 \pm 14$ \\
\hline BMI $\left(\mathrm{kg} / \mathrm{m}^{2}\right)$ & $26.6 \pm 3.4$ \\
\hline Gender (male), n/m (\%) & $41 / 52(79)$ \\
\hline \multicolumn{2}{|l|}{ Pre-operative clinical data } \\
\hline Dyslipidemia, n/m (\%) & 15/52 (29) \\
\hline Hypertension, n/m (\%) & $41 / 52(79)$ \\
\hline Diabetes, n/m (\%) & 0/52 (0) \\
\hline Creatinine $(\mathrm{mg} / \mathrm{dl})$, mean $\pm S D$ & $0.9 \pm 0.2$ \\
\hline Previous cardiac surgery, n/m (\%) & 4/52 (8) \\
\hline $\begin{array}{l}\text { New York Health Association, NYHA, } \\
\text { functional status }>I I, n / m(\%)\end{array}$ & $3 / 52(6)$ \\
\hline Heart failure, n/m (\%) & $8 / 52(15)$ \\
\hline \multicolumn{2}{|l|}{ Pre-operative cardiac characteristics } \\
\hline Ejection fraction (\%), mean \pm SD & $60 \pm 10$ \\
\hline Bicuspid aortic valve, n/m (\%) & $5 / 52(10)$ \\
\hline Valve stenosis, n/m (\%) & 10/52 (19) \\
\hline Valve regurgitation $\geq 11, \mathrm{n} / \mathrm{m}$ (\%) & 10/52 (19) \\
\hline
\end{tabular}

present in $19 \%$ and a bicuspid aortic valve in $10 \%$ of patients. All patients had an aortic root aneurysm and no patients had documented aortic dissection or aortic trauma.

\section{Surgical procedure}

Surgery was performed per clinician discretion. Operative approach chosen for all patients was a full conventional sternotomy. Average aortic cross clamp time was $93 \pm 34 \mathrm{~min}$ and cardioplegia was delivered in anterograde fashion in $69 \%$ of patients, in retrograde in $27 \%$ or both in $4 \%$. Valve surgery was performed (either an aortic valve replacement or leaflet repair) in 35 patients (67\%), while other surgical procedures, other than coronary artery bypass grafting (6\%), were performed in $15 \%$ of patients. Each patient received one CARDIOROOT vascular graft in the thoracic position. The 3 main CARDIOROOT sizes chosen by investigators were 28, 32 and $34 \mathrm{~mm}$, which cover the majority of the sizes used (see Table 2).

\section{Evaluation and endpoints}

Following surgical implantation of the CARDIOROOT graft, the enrolled patients were assessed intraoperatively, post-operatively, at discharge, during readmission (if applicable), at the 30-day follow-up visit, and at 1 year for survival status and any complications. Transthoracic echocardiography data was collected if performed per standard of care.
Table 2 Operative results

\begin{tabular}{ll}
\hline Operative variable & Mean \pm SD or $\mathrm{n} / \mathrm{m}(\%)$ \\
\hline Cardiopulmonary bypass (min), mean \pm SD & $120 \pm 41$ \\
Cross clamp time (min), mean $\pm \mathrm{SD}$ & $93 \pm 34$ \\
Cardioplegia delivery, $\mathrm{n} / \mathrm{m}(\%)$ & \\
Anterograde & $36 / 52(69)$ \\
Retrograde & $14 / 52(27)$ \\
Both & $2 / 52(4)$ \\
Cardioroot diameter (body diameter) & \\
$24 \mathrm{~mm}, \mathrm{n} / \mathrm{m}(\%)$ & $1 / 52(2)$ \\
$26 \mathrm{~mm}, \mathrm{n} / \mathrm{m}$ (\%) & $3 / 52(6)$ \\
$28 \mathrm{~mm}, \mathrm{n} / \mathrm{m}$ (\%) & $15 / 52(29)$ \\
$30 \mathrm{~mm}, \mathrm{n} / \mathrm{m}(\%)$ & $4 / 52(8)$ \\
$32 \mathrm{~mm}, \mathrm{n} / \mathrm{m}$ (\%) & $14 / 52(27)$ \\
$34 \mathrm{~mm}, \mathrm{n} / \mathrm{m}(\%)$ & $15 / 52(29)$ \\
Valve surgery, $\mathrm{n} / \mathrm{m}(\%)$ & $35 / 52(67)$ \\
Coronary artery bypass grafting, $\mathrm{n} / \mathrm{m}(\%)$ & $3 / 52(6)$ \\
Other cardiac procedure, $\mathrm{n} / \mathrm{m}(\%)$ & $8 / 52(5)$ \\
\hline
\end{tabular}

The study endpoint was the overall rate of deaths (all causes) and complications assessed at each visit up to 1-year post CARDIOROOT implant procedure. Participating sites completed a complications form for each assessment time point and also recorded any reported adverse events. Centralized monitoring was performed; source-document verification was limited.

\section{Statistical analysis}

No formal sample size calculation was performed; registry sample size was based upon commitment with the Notified Body at the time of CE mark. Data are presented with number and percentage for all discrete variables and as average \pm standard deviation for all continuous variables. Survival analysis was summarized descriptively by visit, and Kaplan-Meier estimates were provided. Two-sided confidence intervals (CIs) for the survival rate were calculated and presented using Greenwood's formula. The number and percent of observed events (death or complication) at 30 days and 1 year were summarized based on subjects with available data along with the $95 \%$ exact binomial CIs for the percentages. Analysis was done using SAS version 9.4 (SAS Institute, Inc., Cary, NC, USA).

\section{Results}

Fifty of the 52 patients completed the registry (i.e., completed 1-year visit after graft implantation). All procedures were technically successful; no procedures were abandoned or required re-operation. During the 30 postoperative days, 1 patient died due to hemorrhagic shock, yielding an operative survival of $98.1 \%$. Another patient 
died at 5 months after the operation due to pneumonia, bringing the 1-year postoperative survival rate to $96.2 \%$.

A total of 54 complications occurred in 32 patients throughout the follow-up period; $96 \%$ of these occurred within 30 days of the CARDIOROOT implant surgery. The most common was atrial fibrillation, reported in 17 patients (33\%). Four patients required re-operation due to bleeding/tamponade ( 2 acute; 2 late). One patient required a re-operation for cardiac reasons, with sternotomy issues. Two patients suffered from sternal site infections (one superficial; one deep), and required packing/irrigation and wound vacuum-assisted closure. One patient experienced transient paralysis. Two patients reported pneumonia; one within 30 days and one at 5 months post-procedure. One patient experienced an unrelated gastro-intestinal event. Nineteen other complications were recorded but no details were provided. No specific adverse events relating to aortic regurgitation was reported. Transesophageal echocardiography was performed post-operative and at 1-year as per standard of care. Post-operatively, $38.5 \%$ of subjects had no aortic insufficiency, $48.1 \%$ had trace/trivial aortic insufficiency and $11.5 \%$ had mild aortic insufficiency. At 1 year, only $21 / 52$ subjects $(40.4 \%)$ had a recorded transthoracic echocardiography. Six [6] of these subjects had no aortic insufficiency; 9 had trace/trivial aortic insufficiency. Six [6] subjects had mild aortic insufficiency and no patients had moderate to severe aortic insufficiency.

Eleven serious adverse events were reported in 7 patients. The causes were assessed by the local Investigators and were deemed unrelated to the CARDIOROOT

Table 3 Serious Adverse Events

\begin{tabular}{ll}
\hline Serious Adverse Event & Incidence \\
\hline Cardiac disorder & $1(1.9 \%)$ \\
Cardiac tamponade* & $1(1.9 \%)$ \\
Myocardial infarction* & $1(1.9 \%)$ \\
Pericardial effusion* & $1(1.9 \%)$ \\
Pericardial effusion/ Sternal dehiscence* & $1(1.9 \%)$ \\
Ventricular extrasystoles* & \\
Injury, poisoning and procedural complications & $1(1.9 \%)$ \\
Impaired healing/ Sternal wound healing delay* & $1(1.9 \%)$ \\
Postoperative thoracic procedure complication* & \\
Infections and infestations & $1(1.9 \%)$ \\
Pneumonia & $1(1.9 \%)$ \\
Pericardial infection* & \\
Musculoskeletal and connective tissue disorders & $1(1.9 \%)$ \\
Synovial cyst & \\
Vascular disorders & $1(1.9 \%)$ \\
\hline Hemorrhagic shock (death)*
\end{tabular}

device. Nine of the 11 serious adverse events were deemed procedure-related. See Table 3.

\section{Discussion}

The results of this 1-year follow-up study, which involved 52 patients, demonstrate that the CARDIOROOT vascular graft is effective in the treatment of the aortic root disease. The early and mid-term results have confirmed the safety with no anticipated or unanticipated events related to the CARDIOROOT device. Longer term follow-up is required to determine long-term effectiveness of the CARDIOROOT graft.

This registry also confirms the efficacy, as well as the versatility of the graft, given its adoption for both the aortic valve sparing and the Bentall procedure as composite graft.

The unique "drop" shape of the CARDIOROOT graft mimics the physiologic anatomy sinuses of Valsalva. The bulge does not stretch when uploaded, making the Valsalva size more predictable. The shape may permit a more anatomical reconstruction of the sinuses with two potential benefits. In the case of the Florida-Sleeve procedure, where the entire aortic root is spared and wrapped by the graft [9] (Fig. 2), a more physiologic leaflet-sinus unit morphology restoration is expected, reproducing a near normal leaflet-sinus unit morphology [10]. That may ease the transferred part of the leaflet stress to the adjacent sinus of Valsalva wall [11] with a possible benefit on the durability of the procedure. While in the case of a composite graft, the presence of such sinus of Valsalva might have a positive impact on coronary flow dynamics [12], as well as on coronary stress when compared with the straight graft [13]. The three distinct regions of the CARDIOROOT facilitate graft handling and make the size and length of the root more predictable once uploaded by the blood pressure at the end of the operation. Maintaining a stable shape and the size of the aortic root is required to preserve the

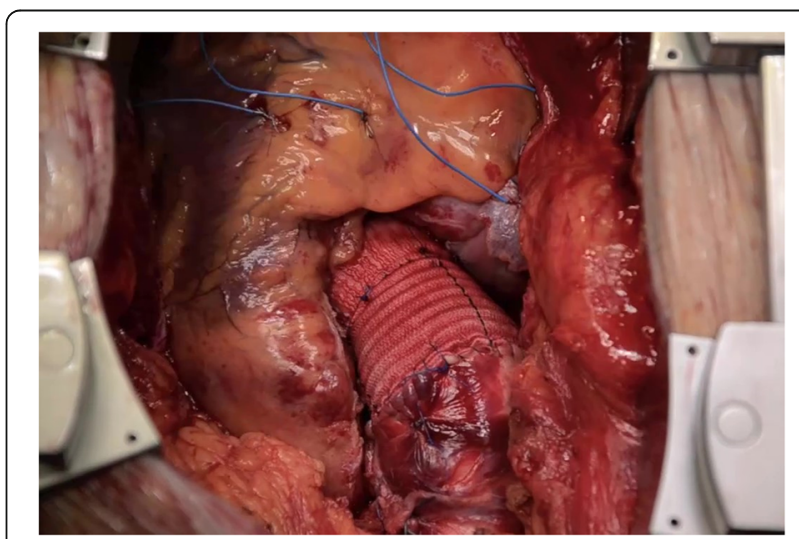

Fig. 2 Cardioroot graft adopted in a Florida-Sleeve sparing aortic valve procedure 
Table 4 Ethics Committees

\begin{tabular}{|c|c|}
\hline Investigator / Site & Ethics Committee \\
\hline $\begin{array}{l}01 \text { Laurent Barandon, MD / } \\
\text { Centre Hospitalier } \\
\text { Universitaire (CHU) de } \\
\text { Bordeaux } \\
\text { Department of Cardiac and } \\
\text { Vascular Surgery } \\
\text { Bordeaux. France }\end{array}$ & $\begin{array}{l}\text { Comité de Protection Des Personnes } \\
\text { Sud-Ouest et Outre Mer III } \\
146 \text { Rue Léo Saignat, 33,000 Bordeaux, } \\
\text { France }\end{array}$ \\
\hline $\begin{array}{l}02 \text { Prof. Jaroslav Lindner / } \\
\text { Chirurgická klinika } \\
\text { kardiovaskulární chirurgie } \\
\text { General University Hospital in } \\
\text { Prague } \\
\text { Prague. Czech Republic }\end{array}$ & $\begin{array}{l}\text { Etická komise } \\
\text { Všeobecné fakultní nomocnice v Praze } \\
\text { (Ethics Committee of the General } \\
\text { University Hospital in Prague) } \\
\text { Na Bojišti } 1 \\
12808 \text { Prague } 2 \\
\text { Prague, Czech Republic } \\
\text { Chairman: MUDr. Josef Šedivý, Csc. } \\
\text { Date: } 18 \text { Oct } 2012\end{array}$ \\
\hline $\begin{array}{l}03 \text { Petr Šantavý, MD, PhD / } \\
\text { Kardiochirurgická klinika } \\
\text { University Hospital Olomouc } \\
\text { Olomouc. Czech Republic }\end{array}$ & $\begin{array}{l}\text { Fakultní Nemocnice Olomouc } \\
\text { Etická komise Fakultní nemocnice } \\
\text { Olomouc a Lékařske fakulty UP v } \\
\text { Olomouci } \\
\text { (Ethics Committee of the University } \\
\text { Hospital Olomouc) } \\
\text { I.P. Pavlova } 677520 \text { Olomouc, Czech } \\
\text { Republic } \\
\text { Chairman: doc. MUDr. Vladko Horčička, } \\
\text { Csc. } \\
\text { Approval date: } 18 \text { February } 2013\end{array}$ \\
\hline $\begin{array}{l}04 \text { Jan Burkert, MD, PhD / } \\
\text { Klinika kardiovaskulární } \\
\text { chirurgie } \\
\text { University Hospital Motol, } \\
\text { Dept. Cardiac Surgery } \\
\text { Motol. Czech Republic }\end{array}$ & $\begin{array}{l}\text { Etická komis FN MOTOL } \\
\text { V úvalu } 84 \\
15006 \text { Praha } 5 \text { - Motol, Czech Republic } \\
\text { Chairman: MU Dr. Jiř́ Škopek, PhD. } \\
\text { Approval date: } 13 \text { November } 2013\end{array}$ \\
\hline $\begin{array}{l}05 \text { Amando Gamba MD / } \\
\text { Giordano Tasca / } \\
\text { Cardiac Surgery } \\
\text { Ospedale Manzoni di Lecco } \\
\text { Lecco, Italy }\end{array}$ & $\begin{array}{l}\text { Comitato Etico Interaziendale delle } \\
\text { Province di Lecco, Como e Sondrio } \\
\text { Via dell'Eremo 9/1123900 Lecco, Italy } \\
\text { Chairman: Dr. Antonio Giuseppe } \\
\text { Cusumano } \\
\text { Approval date: } 12 \text { Mar } 2013\end{array}$ \\
\hline $\begin{array}{l}06 \text { Prof. Carlo Antona / } \\
\text { Ospedale Luigi Sacco Polo } \\
\text { Universitario Dip } \\
\text { Cardiocerebrovascolare } \\
\text { Milan, Italy }\end{array}$ & $\begin{array}{l}\text { Eitco Interaziendale Milano Area } \\
\text { Ospedale Luigi Sacco Polo Universitario } \\
\text { Milan. Italy } \\
\text { Chairman: Prof. Emilio Trabucchi } \\
\text { Approval date: } 21 \text { Nov } 2014\end{array}$ \\
\hline
\end{tabular}

correct size ratio among the different components of the aortic root and in particular between the annulus and sinotubular junction. While this may have a favorable impact on valve or prosthesis function and should prolong the durability of a sparing aortic valve procedure, in the case of the composite graft, the stability in aortic root geometry may be useful in maintaining an optimized valve prosthesis fluid dynamics performance [14, 15].

While this registry was a multi-center, prospective registry, there are several limitations to note. The registry employed centralized monitoring and did not include full source document verification. Specific surgical information was not considered during data collection. The registry follow-up is limited to 1 year; further data for longer term follow-up is needed. The registry was also restricted by the nature of the procedures included by sites to aneurysmal disease and did not address dissection or other uses of the CARDIOROOT graft.

\section{Conclusions}

The results of this registry demonstrated early and mid-term safety and effectiveness of the CARDIOROOT vascular grafts for the treatment of aneurysmal aortic root. The graft is fit for both the aortic sparing valve procedure and aortic root replacement as a composite graft.

\section{Abbreviations \\ CE: Conformité Européene; Cl: Confidence interval; SD: Standard deviation}

\section{Acknowledgements}

The authors thank all site personnel who contributed to the execution and conduct of the registry. Editorial assistance was provided by Intervascular, SAS.

Funding

The registry was funded by Intervascular, SAS.

\section{Availability of data and materials}

The datasets used and/or analyzed during the current study are available from the corresponding author on reasonable request.

\section{Authors' contributions \\ GT is the corresponding author and has been responsible for the interpretation of the data and drafting and writing of the manuscript. AG participated in the design of the registry and its coordination and helped draft the manuscript. Statistical analysis was performed by Stat-Tech, funded by Intervascular. All authors made substantial contributions to the design and/or acquisition of the data. All authors read and approved the final manu- script. All authors agreed to be accountable for all aspects of the work.}

\section{Ethics approval and consent to participate}

Ethics approval for this registry was obtained from the ethics review committee from participating centers. The patients included in the registry provided their informed consent. For a list of sites and respective ethics committees, please see Table 4. This manuscript has been reviewed and approved by all the co-authors, and has not been submitted to any other journals for consideration for publication.

Consent for publication

Not applicable.

\section{Competing interests}

The authors declare that they have no competing interests.

\section{Publisher's Note}

Springer Nature remains neutral with regard to jurisdictional claims in published maps and institutional affiliations.

\footnotetext{
Author details

'Operative Unit of Cardiac Surgery, Cardiovascular Department, ASST-Lecco, Ospedale "A. Manzoni", Via Dell'Eremo 9/11, 23900 Lecco, Italy. ${ }^{2}$ Chirurgická klinika kardiovaskulární chirurgie, General University Hospital, Prague, Czech Republic. ${ }^{3}$ Department of Cardiac and Vascular Surgery, Centre Hospitalier Universitaire (CHU) de Bordeaux, Bordeaux, France. ${ }^{4}$ Kardiochirurgická klinika, University Hospital Olomouc, Olomouc, Czech Republic. ${ }^{5}$ Università degli Studi di Milano, Division of Cardio-Vascular Surgery, Department of Cardio-Cerebro-Vascular, ASST Fatebenefratelli-Sacco, Milan, Italy. ${ }^{6}$ Dept. Cardiac Surgery, Klinika kardiovaskulární chirurgie, University Hospital Motol, Motol, Czech Republic.
} 
Received: 20 February 2019 Accepted: 13 May 2019

Published online: 21 May 2019

\section{References}

1. David TE. Aortic valve sparing operations: outcomes at 20 years. Ann Cardiothorac Surg. Jan. 2013;2(1):24-9.

2. De Paulis R, De Matteis GM, Nardi P, Scaffa R, Buratta MM, Chiariello L. Opening and closing characteristics of the aortic valve after valve-sparing procedures using a new aortic root conduit. Ann Thorac Surg. 2001;72(2): 487-94.

3. Matsumori M, Tanaka H, Kawanishi Y, Onishi T, Nakagiri K, Yamashita T, et al. Comparison of distensibility of the aortic root and cusp motion after aortic root replacement with two reimplantation techniques: Valsalva graft versus tube graft. Interact Cardiovasc Thorac Surg. 2007;6(2):177-81.

4. Alimi Y, Juhan C, Morati N, Girard N, Cohen S. Dilation of woven and knitted aortic prosthetic grafts: CT scan evaluation. Ann Vasc Surg. 1994;8(3):238-42.

5. Franke U, Jurmann MJ, Uthoff $K$, Kohler A, Jurmann B, Wahlers $T$, et al. In vivo morphology of woven, collagen-sealed Dacron prostheses in the thoracic aorta. Ann Thorac Surg. 1997;64(4):1096-8.

6. Utoh J, Goto H, Hirata T, Hara M, Kitamura N. Dilatation of sealed Dacron vascular prostheses: a comparison of Gelseal and Hemashield. J Cardiovasc Surg. 1998;39(2):179-80.

7. Singh C, Wong CS, Wang X. Medical textiles as vascular implants and their success to mimic natural arteries. Journal of functional biomaterials. 2015; 6(3):500-25

8. Hirt SW, Aoki M, Demertzis S, Siclari F, Haverich A, Borst HG. Comparative in vivo study on the healing qualities of four different presealed vascular prostheses. J Vasc Surg. 1993;17(3):538-45.

9. Gamba A, Tasca G, Giannico F, Lobiati E, Skouse D, Galanti A, et al. Early and medium term results of the sleeve valve-sparing procedure for aortic root ectasia. Ann Thorac Surg. 2015;99(4):1228-33.

10. Tasca G, Selmi M, Votta E, Redaelli P, Sturla F, Redaelli A, et al. Aortic root biomechanics after sleeve and David sparing techniques: a finite element analysis. Ann Thorac Surg. 2017;103(5):1451-9.

11. Tasca G, Selmi M, Votta E. Reply. Ann Thorac Surg. 2018;105(3):984-5.

12. De Paulis R, Tomai F, Bertoldo F, Ghini AS, Scaffa R, Nardi P, Chiariello L. Coronary flow characteristics after a Bentall procedure with or without sinuses of Valsalva. Eur J Cardiothorac Surg. 2004 Jul;26(1):66-72.

13. Weltert L, De Paulis R, Scaffa R, Maselli D, Bellisario A, D'Alessandro S. Recreation of a sinuslike graft expansion in Bentall procedure reduces stress at the coronary button anastomoses: a finite element study. J Thorac Cardiovasc Surg. 2009;137(5):1082-7.

14. Barannyk $O$, Oshkai $P$. The influence of the aortic root geometry on flow characteristics of a prosthetic heart valve. J Biomech Eng. 2015;137(5): 051005

15. Toninato R, Salmon J, Susin FM, Ducci A, Burriesci G. Physiological vortices in the sinuses of Valsalva: an in vitro approach for bio-prosthetic valves. J Biomech. 2016:49(13):2635-43.

Ready to submit your research? Choose BMC and benefit from:

- fast, convenient online submission

- thorough peer review by experienced researchers in your field

- rapid publication on acceptance

- support for research data, including large and complex data types

- gold Open Access which fosters wider collaboration and increased citations

- maximum visibility for your research: over $100 \mathrm{M}$ website views per year

At $\mathrm{BMC}$, research is always in progress.

Learn more biomedcentral.com/submissions 